\title{
Column studies for biosorption of dyes from aqueous solutions on immobilised Aspergillus niger fungal biomass
}

\author{
Yuzhu Fu and T Viraraghavan* \\ Faculty of Engineering, University of Regina, Regina, Saskatchewan, Canada S4S OA2
}

\begin{abstract}
Biosorption is becoming a promising alternative to replace or supplement the present dye removal processes from dye wastewaters. Based on the results of batch studies on biosorption of the dyes on powdered fungal biomass, Aspergillus niger, an immobilised fungal biomass was used in column studies for removal of four dyes, Acid Blue 29, Basic Blue 9, Congo Red and Disperse Red 1 from aqueous solutions. For each dye, the effectively pretreated powdered fungal biomass was immobilised in a polysulphone matrix in the form of spherical beads. In column studies, adsorption and elution tests were conducted for each dye and the regeneration and reuse for Acid Blue 29 were carried out. The breakthrough data from column studies could be described by the Thomas model. Results of t-tests indicated that the Thomas model constants were statistically significant at 95\% confidence level for Acid Blue 29 and Basic Blue 9, but not for Congo Red and Disperse Red 1. The beads had adsorption capacities of $64.7 \mathrm{mg} /$ g for Acid Blue 29, $8.3 \mathrm{mg} / \mathrm{g}$ for Basic Blue 9, $1.1 \mathrm{mg} / \mathrm{g}$ for Congo Red, and $0.1 \mathrm{mg} / \mathrm{g}$ for Disperse Red 1, respectively. In the elution tests, Acid Blue 29 and Basic Blue 9 were easily desorbed from the beads, but Congo Red and Disperse Red 1 were minimally desorbed. The beads in the column retained a high adsorption capacity (91\%) for Acid Blue 29 in the second cycle, which suggested that the system using A. niger biomass can be developed for the removal of certain dyes.
\end{abstract}

Key words: Aspergillus niger, immobilisation, Acid Blue 29, Basic Blue 9, Congo Red, Disperse Red 1.

\section{Introduction}

Dye wastewaters discharged from textile and dyestuff industries have to be treated due to their impact on water bodies, and growing public concern over their toxicity and carcinogenicity in particular. Dyes usually have synthetic origins and complex aromatic molecular structures (Banat et al., 1996). According to their dissociation in an aqueous solution, dyes can be classified as follows (Mishra and Tripathy, 1993):

- Anionic: acid, direct and reactive dyes

- Cationic: basic dyes

- Nonionic: disperse dyes.

Dyes such as acid, basic and direct are all water-soluble (Reife, 1990) but disperse dyes have low solubilities and colloidal dispersion properties; thus they are agglomerations (Reife and Freeman, 1996). Many different and complicated molecular structures of dyes make dye wastewaters difficult to be treated by conventional biological and physico-chemical processes. Therefore, innovative treatment technologies need to be investigated.

Biosorption has been studied since 1980s for removing heavy metals, dyes and other organic pollutants by various microorganisms from wastewater. Among these microorganisms, fungal biomass can be produced cheaply and obtained as a waste from various industrial fermentation processes (Kapoor and Viraraghavan, 1995). Decolorisation of dye wastewater by fungal metabolic activities is the subject of many studies (Benito et al., 1997; Knapp et al., 1995; Miranda et al., 1996; Polman and Breckenridge, 1996; Vasdev et al., 1995). Compared with live fungal cells, dead fungal biomass possesses various advantages

\footnotetext{
* To whom all correspondence should be addressed.

T표 (306) 585-4734; fax: (306)585-4855; e-mail:t.viraraghavan@uregina.ca Received 26 January 2001; accepted in revised form 9 July 2003.
}

such as absence of nutrient needs and ease of regeneration (Gadd, 1990). Dried, non-living and physically or chemically pretreated fungal biomass would be an attractive biosorbent for removing dyes from dye wastewaters. However, there are only limited studies on dye removal by dead fungal biomass (Fu and Viraraghavan, 1999; 2000; Gallagher et al., 1997; Polman and Breckenridge, 1996; Zhou and Banks, 1993; Mou et al., 1991). These fungi, which can biosorb diverse dyes, include Aspergillus niger, Rhizopus arrhizus and Rhizopus oryzae.

In batch studies, the dead fungal biomass is normally used in the powdered form, which is convenient and can be separated from a mixture of dye solution and fungal biomass by filters with a fine pore size without difficulty. However, the fungal biomass powder is composed of small particles with low density, low mechanical strength and low rigidity. These properties will cause difficulties in separation of the biomass in practice (Tsezos, 1990). Alternatively, immobilisation of the powdered dead fungal biomass into a solid matrix can overcome this difficulty. It can maintain the native properties of the biomass and has the advantages of improved strength and handling capacity, reduced blockage and head-loss in a column operation and better regeneration characteristics (Tobin et al., 1993; Brierley, 1990; Tsezos, 1990).

Two kinds of fungal biomass, live and dead, are used in immobilisation. Banks and Parkinson (1992) immobilised living fungal cells, Rhizopus arrhizus within the reticulated foam biomass support particles and used these immobilsed cells in columns to remove humic acid from the raw water. In the immobilisation of dead fungal biomass for heavy metals removal, various materials can be used as the solid matrix. These are polysulphone, alginate, polyacrylamide, epoxy resin and polyvinyl formal (Kapoor and Viraraghavan, 1998; Spinti et al., 1995; Ferguson et al., 1989; Tobin et al., 1993; Tsezos and Deutschmann, 1990). Polysulphone is an amorphous, rigid, heat-resistant and chemically stable thermoplastic material which is a good immobilising agent (Kapoor and Viraraghavan, 1998). So far no study of dead fungal biomass 
immobilised onto polysulphone solid matrix has been conducted on dye removal from aqueous solutions.

In this study, immobilised dead fungal biomass, Aspergillus niger, in polysulphone in the form of spherical beads was used in column studies for removing each of the four dyes, Acid Blue 29, Basic Blue 9, Congo Red and Disperse Red 1 from aqueous solutions, respectively, based on the results of batch studies. A procedure for the immobilisation of dead powdered fungal biomass in polysulphone to form spherical beads was developed. The characteristics of beads such as size distribution and specific surface area were studied. Column studies were conducted to evaluate the adsorption capacity of beads for dye removal. Finally, the dye elution, regeneration and reuse of such beads in columns were examined.

\section{Materials and methods}

\section{Dye solution preparation}

The dyes used in this study are presented in Table 1. They were supplied by Sigma Chemical Company, St Louis, MO, USA.

Dye solutions were prepared by dissolving accurately weighed dyes in distilled water at a concentration of $50 \mathrm{mg} / \ell$. The $\mathrm{pH}$ of each dye solution was adjusted to its effective $\mathrm{pH}$ obtained from the results of the batch studies (Table 2). To compare dye removal on the same basis, the $\mathrm{pH}$ of all the samples was adjusted to 7.6 before measurement. Dilute $\mathrm{HCl}$ or $\mathrm{NaOH}$ was used for $\mathrm{pH}$ adjustment. The concentration of dye solution was determined using a spectrophotometer (Baush \& Lomb-Spectromic 21) operating in the visible range on absorbance mode. Absorbance values were recorded at the corresponding maximum absorbance wavelength $\left(\lambda_{\max }\right)$ (given in Table 1$)$ and dye solution was initially calibrated for concentration in terms of absorbance units. The concentration of the dye solution was obtained from its calibration plot.

\section{Fungal biomass preparation}

The A. niger strain used in this study was obtained from the American Type Culture Collection, Rockville, Maryland, USA (ATCC\#11414). The culturing procedure, growth media and different pretreatments have been described previously (Fu and Viraraghavan, 1999; 2000). The fungal pellicles were separated by filtering the growth media through a $150 \mu \mathrm{m}$ sieve and washed with generous amounts of deionised water. They were pretreated by the methods found most effective for enhancement of biosorption of each dye (Table 2) based on batch studies (Fu and Viraraghavan, 1999; 2000). The effectively pretreated biomasses were washed with generous amounts of deionised water until the $\mathrm{pH}$ of the wash solution was close to that of deionised water $(\mathrm{pH}=6.0)$, autoclaved for $30 \mathrm{~min}$ at $121^{\circ} \mathrm{C}$ and $124 \mathrm{kPa}$ and then dried in an oven at 60 to $70^{\circ} \mathrm{C}$ for $36 \mathrm{~h}$. The dry biomass was ground to powder using a mortar and a pestle. The powdered biomass was sieved through a sieve with openings of $150 \mu \mathrm{m}$ and powder with particles less than or equal to $150 \mu \mathrm{m}$ was used in immobilisation.

\section{Fungal biomass immobilisation}

Fourteen gram of powdered biomass was blended into a solution containing $7 \mathrm{~g}$ of polysulphone (obtained from Aldrich Chem., Cat No. 18244-3, avg. mol. wt. 44000 to 53000 ) per $100 \mathrm{~m} \ell$ of
TABLE 1

Summary data on dyes studied

\begin{tabular}{|l|l|r|r|r|}
\hline Name & Classification & C.I. & FW & $\begin{array}{r}\lambda_{\max } \\
(\mathbf{n m})\end{array}$ \\
\hline Acid Blue 29 & Anionic disazo & 20460 & 616.5 & 600 \\
Basic Blue 9 & Cationic thiazine & 52015 & 373.9 & 660 \\
Congo Red & Anionic direct disazo & 22120 & 696.7 & 500 \\
Disperse Red 1 & Nonionic monoazo & 11110 & 314.3 & 450 \\
\hline
\end{tabular}

Note: C.I. = color index; FW = formula weight;

$\lambda_{\max }=$ maximum absorbance wavelength.

\section{Summary of data from batch studies \\ TABLE 2}

\begin{tabular}{|c|c|c|c|c|}
\hline Name & $\begin{array}{l}\text { Effective biomass } \\
\text { pretreatment }\end{array}$ & $\begin{array}{l}\text { Effective } \\
\text { initial pH }\end{array}$ & $\begin{array}{l}\text { Equilibrium } \\
\text { time (h) }\end{array}$ & $\begin{array}{l}\text { Effective } \\
\text { elutant }\end{array}$ \\
\hline Acid Blue 29 & $\mathrm{H}_{2} \mathrm{SO}_{4}+$ Autoclaved & 4.0 & 24 & $0.1 \mathrm{M} \mathrm{NaOH}$ \\
\hline Basic Blue 9 & Autoclaved & 6.0 & 30 & $0.01 \mathrm{M} \mathrm{HCl}$ \\
\hline Congo Red & $\mathrm{NaHCO}_{3}+$ Autoclaved & 6.0 & 42 & $0.01 \mathrm{MNaOH}$ \\
\hline Disperse Red 1 & $\mathrm{NaOH}+$ Autoclaved & 4.0 & 48 & $0.05 \mathrm{M} \mathrm{NaOH}$ \\
\hline
\end{tabular}

\begin{tabular}{|l|l|c|c|c|}
\hline Name & $\begin{array}{l}\text { Effective biomass } \\
\text { pretreatment }\end{array}$ & $\begin{array}{c}\text { Effective } \\
\text { initial pH }\end{array}$ & $\begin{array}{c}\text { Equilibrium } \\
\text { time (h) }\end{array}$ & $\begin{array}{c}\text { Effective } \\
\text { elutant }\end{array}$ \\
\hline Acid Blue 29 & $\mathrm{H}_{2} \mathrm{SO}_{4}+$ Autoclaved & 4.0 & 24 & $0.1 \mathrm{M} \mathrm{NaOH}$ \\
Basic Blue 9 & Autoclaved & 6.0 & 30 & $0.01 \mathrm{M} \mathrm{HCl}$ \\
Congo Red & $\mathrm{NaHCO}_{3}+$ Autoclaved & 6.0 & 42 & $0.01 \mathrm{MNaOH}$ \\
Disperse Red 1 & $\mathrm{NaOH}+$ Autoclaved & 4.0 & 48 & $0.05 \mathrm{M} \mathrm{NaOH}$ \\
\hline
\end{tabular}

n, n-dimethyl-formamide (DMF, obtained from Aldrich Chemicals) The mixture was shaken for $24 \mathrm{~h}$ on a rotary shaker at 125 $\mathrm{r} \cdot \mathrm{min}^{-1}$ to dissolve polysulphone completely in DMF and form a uniform and consistent slurry. The slurry was fed through an atomising unit into a deionised water bath. The atomising unit consisted of a stainless steel tube surrounding another stainless center tube of $4 \mathrm{~mm}$ diameter. The DMF-polysulphone-biomass slurry was fed into the holding cylinder and then allowed to flow into the centre tube. A needle valve controlled the flow rate of the slurry. Pressurised air was pumped in the annular space between the surrounding and centre tube at a rate of approximately 22.65 $\ell / \mathrm{min}$. The slurry was atomised at the tip by flowing air. Spherical beads were formed when the atomised slurry contacted with water because of the phase inversion of polysulphone. The biomass was immobilised within the solidified polysulphone matrix. The DMF completely dissolved in water and gradually diffused out which led to the formation of a favourable pore structure for the spherical beads. Beads were cured in a moderately agitated deionised water bath in a rotary shaker at $100 \mathrm{r} \cdot \mathrm{min}^{-1}$ for $24 \mathrm{~h}$ to diffuse out the DMF. After curing, beads were air-dried for $3 \mathrm{~d}$ at room temperature $\left(22 \pm 1^{\circ} \mathrm{C}\right)$ and irregularly shaped beads were discarded.

\section{Removal by polysulphone beads}

To determine the removal effect by polysulphone itself, polysulphone beads were also produced in this study, $14 \mathrm{~g}$ of powdered biomass was replaced by $7 \mathrm{~g}$ of polysulphone. Other processes were the same as fungal biomass immobilisation. Polysulphone beads were passed through a sieve with $0.6 \mathrm{~mm}$ openings. The beads with a diameter smaller than $0.6 \mathrm{~mm}$ were used in batch studies for dye removal. Two-tenths of a gram polysulphone beads were added in $75 \mathrm{~m} \ell$ of dye solution at its effective initial $\mathrm{pH}$ and the mixture was shaken for a period equal to the equilibrium time corresponding to the dye at $125 \mathrm{r} \cdot \mathrm{min}^{-1}$. Meanwhile, as a blank, $75 \mathrm{~m} \ell$ of dye solution without the polysulphone beads was also shaken under the same 
conditions. The mixture and blank were vacuum filtered through a $0.45 \mathrm{~mm}$ filter. The filtrate was analysed for the dye concentration and the dye adsorbed by the polysulphone beads was calculated.

\section{Sieve analysis}

Sieve analysis was used to determine the size distribution of the beads. The sieves' openings ( $\mathrm{mm}$ ) were $4.75,3.35,2.36,1.18,0.85$ and 0.6. Beads greater than $4.75 \mathrm{~mm}$ and smaller than $0.6 \mathrm{~mm}$ were discarded. The uniform coefficient $\left(\mathrm{C}_{\mathrm{u}}\right)$ was calculated using the following equation (Das, 1997):

$$
C_{u}=\frac{D_{60}}{D_{10}}
$$

where:

D refers to the diameter of the beads and the subscripts 10, 60 are the percent finer

$\mathrm{D}_{10}$ is referred to as the effective size of the beads.

\section{Measurement of surface area}

The surface area of the beads (1.18 to $2.36 \mathrm{~mm}$ ) was determined by Flowsorb 2300 manufactured by Micromeritics, Georgia, U.S.A. Single point surface area was chosen to measure the surface area of the beads. The gas mixture was composed of $29 \%$ mole nitrogen and $71 \%$ mole helium. It is a favourable condition for the formation of a monolayer molecules of adsorbed nitrogen on the surface area of porous biomass - polysulphone beads at atmospheric pressure and the temperature of liquid nitrogen. The area covered by each nitrogen gas molecule is known within relatively narrow limits. Therefore, the area of the sample can be directly calculated from the number of adsorbed nitrogen molecules derived from the gas quantity at the prescribed conditions, and the area occupied by each molecule.

\section{Column studies}

Four and half gram of the immobilised biomass beads was packed into a glass column which had an inside diameter of $1.27 \mathrm{~cm}$ and a height of $40 \mathrm{~cm}$. At the top and bottom of the beads in the column, one layer of gravel with a height of $3 \mathrm{~cm}$ was used to distribute influent dye solution and support beads, respectively. To maintain a water head (about $5 \mathrm{~cm}$ ) above the top of the beads in the column, the outlet was set at a certain level, almost the same as the designed water level in the column. The parameters related to column studies are given in Table 3.

Before the dye solution was passed through the column, deionised water was pumped through the column in a downflow direction to wet the beads completely. Each dye solution was then pumped into the column in a downflow direction by a peristaltic pump at a specified rate (Table 3). Two flow rates for each of the dyes, Congo Red and Disperse Red 1, were used because the higher one caused a rapid breakthrough. Effluent samples were collected at regular intervals ( $15 \mathrm{~min}$ for the first hour, every $30 \mathrm{~min}$ from the first hour to the fourth hour, and then at longer intervals) and analysed for $\mathrm{pH}$ and dye concentrations. When the concentration ratio of effluent to influent reached a value over 0.8 , the column was considered to be exhausted and the pump was stopped.

Dyes adsorbed on the beads in the column were eluted by the elutants found effective (Table 2). The elutant was pumped into the column in the downflow direction with the same flow rate as in the adsorption column test. The eluted samples were collected at intervals varying from $1 \mathrm{~min}$ to $30 \mathrm{~min}$ (1 min for the first $2 \mathrm{~min}$,
TABLE 3

The parameters of the column studied

\begin{tabular}{|l|c|c|c|c|}
\hline Dye & $\mathbf{H}(\mathbf{c m})$ & $\mathbf{V}(\mathbf{m} \boldsymbol{l})$ & $\mathbf{Q}(\mathbf{m} \boldsymbol{\ell} / \mathbf{m i n})$ & $\mathbf{T}(\mathbf{m i n})$ \\
\hline Acid Blue 29 & 23.5 & 29.8 & 6 & 5.0 \\
Basic Blue 9 & 24.5 & 31.0 & 6 & 5.2 \\
Congo Red & 24.5 & 31.0 & $6(3)$ & $5.2(10.4)$ \\
Disperse Red 1 & 22.5 & 28.5 & $6(3)$ & $5.2(10.4)$ \\
\hline
\end{tabular}

Note: $\mathrm{H}$ = height; $\mathrm{V}=$ volume; $\mathrm{Q}=$ flow rate;

$\mathrm{T}=$ retention time.

The numbers in brackets relate to the second fow rate used.

every $2 \mathrm{~min}$ from $2 \mathrm{~min}$ to $6 \mathrm{~min}$, every $4 \mathrm{~min}$ from $6 \mathrm{~min}$ to $10 \mathrm{~min}$, every $5 \mathrm{~min}$ from $10 \mathrm{~min}$ to $20 \mathrm{~min}$, every $10 \mathrm{~min}$ from $20 \mathrm{~min}$ to $30 \mathrm{~min}$, every $15 \mathrm{~min}$ from $30 \mathrm{~min}$ to $1 \mathrm{~h}$, and every $30 \mathrm{~min}$ after $1 \mathrm{~h}$ ) and analysed for dye concentrations. When the dye concentration of the elutant reached about $1.5 \mathrm{mg} / \ell$, the elution test was stopped.

In the studies on regeneration and reuse, only the beads in the column for removal of Acid Blue 29 were chosen because this dye showed the best results in the batch studies on elution, regeneration and reuse of the biomass among the four dyes. After elution, the biomass beads were regenerated by deionised water based on the results of the batch study. Deionised water was pumped into the column in the downflow direction at the same flow rate as in the adsorption test. When the $\mathrm{pH}$ of the regeneration effluent was close to the $\mathrm{pH}$ of deionised water, the regeneration process was stopped. The second cycle of the adsorption column test for removal of Acid Blue 29 was conducted as described for the first cycle.

Various mathematical models can be used to describe fixedbed adsorption. Among these the Thomas (1948) model is simple to use in the design of a fixed-bed adsorption column. Therefore the breakthrough data obtained from the column studies was examined using the kinetic model developed by Thomas (1948). The expression of the Thomas model for an adsorption column is as follows (Reynolds and Richards, 1996):

$$
\frac{C}{C_{0}} \approx \frac{1}{1+\exp \left[\frac{k}{Q}\left(q_{0} M-C_{0} V\right)\right]}
$$

where:

$\mathrm{C}=$ effluent dye concentration, $\mathrm{mg} / \ell$

$\mathrm{C}_{0}=$ initial dye concentration, $\mathrm{mg} / \ell$

$\mathrm{k}=$ Thomas rate constant, $\ell /$ min.mg

$\mathrm{q}_{0}=$ maximum dye adsorption capacity of the beads, $\mathrm{mg} / \mathrm{g}$

$\mathrm{M}=$ mass of the beads, $\mathrm{g}$

$\mathrm{V}=$ throughput volume of the dye solution, $\mathrm{m} \ell$

$\mathrm{Q}=$ flow rate, $\mathrm{m} \ell / \mathrm{min}$.

Equation (2) can be converted to the simple format as follows:

$$
\frac{C}{C_{0}} \approx \frac{1}{1+\exp (b-a V)}
$$

where:

$$
a=\frac{k C_{0}}{Q}
$$




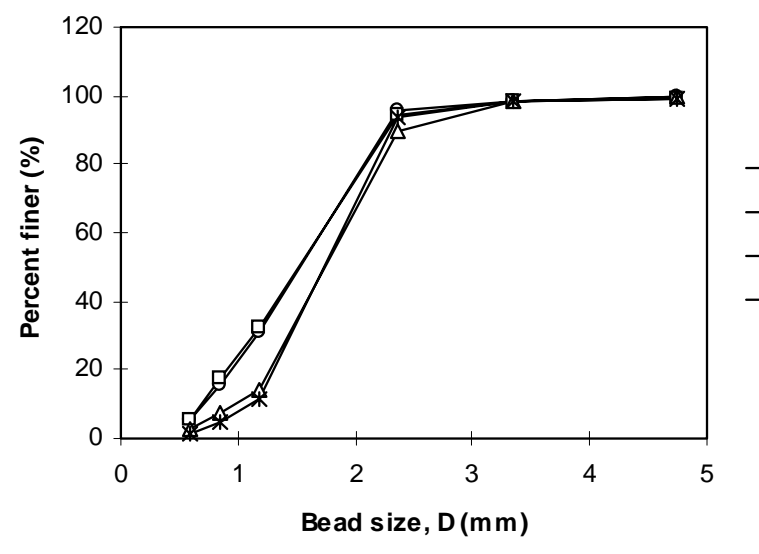

$$
b=\frac{k q_{0} M}{Q}
$$

Therefore, if $\mathrm{Q}, \mathrm{M}$ and $\mathrm{C}_{0}$ are constants, $\mathrm{C} \mathrm{C}_{0}$ is the function of $\mathrm{V}$. Once $\mathrm{a}$ and $\mathrm{b}$ are determined, $\mathrm{k}$ and $\mathrm{q}_{0}$ can be calculated by the following formula derived from Eqs. (4) and (5):

$$
\begin{gathered}
k=\frac{a Q}{C_{0}} \\
q_{0}=\frac{b Q}{k M}
\end{gathered}
$$

The Thomas model was analysed by non-linear estimation included in STATISTICA software (Release 5, 1997 edition) for WINDOWS by the Quasi-Newton method.

\section{Results and discussion}

\section{Bead production}

The beads produced by the methods described above were spherical in shape and greyish white in color. In the experiment, it was observed that the flow rates of slurry of DMF-polysulphonebiomass and air were important factors affecting the bead size distribution. As expected, increasing the flow rate of slurry caused the bigger beads to be formed, while increasing the flow rate of air resulted in smaller beads being produced. Finally, the air flow rate was fixed at about $22.65 \mathrm{l} / \mathrm{min}$ and the needle valve in the fabrication unit was used to control the flow rate of the slurry.

\section{Sieve analysis}

Figure 1 shows the results of the sieve analysis for the four kinds of beads developed from the different pretreated biomasses. They had a similar size distribution. The curves of percent finer versus sieve opening almost overlapped each other. About 60 to $80 \%$ of beads were in the size range of 1.18 to $2.36 \mathrm{~mm}, 61.5 \%$ for beads developed from autoclaved pretreated biomass (corresponding to Basic Blue 9 removal) and 82.4\% for beads containing $\mathrm{NaOH}$ plus autoclaved pretreated biomass (corresponding to Disperse Red 1 removal), respectively. The effective sizes and uniformity coefficients for the four different beads are given in Table 4 .

Kapoor and Viraraghavan (1998) observed that the beads developed from the $\mathrm{NaOH}$ pretreated A. niger biomass and polysulphone had an effective size of $0.718 \mathrm{~mm}$ and a uniformity coefficient of 2.17, which were comparable with the results obtained in this study. The size distribution of the four kinds of beads used in the column studies is given in Table 5 .
Figure 1

Sieve analysis for the beads made of different pretreated $(P T)$ biomass

TABLE 4

\begin{tabular}{|c|c|c|c|c|}
\hline $\begin{array}{l}\text { Dye removed } \\
\text { by beads }\end{array}$ & $\begin{array}{c}\text { Effective } \\
\text { size }\left(D_{10}\right) \\
(\mathrm{mm})\end{array}$ & $\begin{array}{c}\text { Uniformity } \\
\text { coefficient } \\
\left(C_{u}\right)\end{array}$ & $\begin{array}{c}\text { Specific } \\
\text { surface } \\
\text { area } \\
\left(\mathrm{m}^{2} / \mathrm{g}\right)\end{array}$ & $\begin{array}{l}\text { Adsorption } \\
\text { capacity of } \\
\text { polysulfone } \\
\text { bead(mg/g) }\end{array}$ \\
\hline Acid Blue 29 & 0.7 & 2.43 & 2.40 & 0.63 \\
\hline Basic Blue 9 & 1.1 & 1.68 & 3.16 & 1.70 \\
\hline Congo Red & 0.9 & 2.06 & 2.86 & 0 \\
\hline Disperse Red 1 & 0.7 & 2.43 & 2.54 & 0.44 \\
\hline
\end{tabular}

Characteristics of beads used in the column studies and adsorption capacity of polysulphone beads

\begin{tabular}{|c|c|c|c|c|}
\hline \multicolumn{5}{|c|}{$\begin{array}{c}\text { TABLE 5 } \\
\text { Size distribution of the beads used in the } \\
\text { column studies }\end{array}$} \\
\hline $\begin{array}{c}\text { Size of } \\
\text { beads (mm) }\end{array}$ & \multicolumn{4}{c|}{ Per cent (\%) } \\
\cline { 2 - 5 } & $\begin{array}{c}\text { Acid } \\
\text { Blue 29 }\end{array}$ & $\begin{array}{c}\text { Basic } \\
\text { Blue 9 }\end{array}$ & $\begin{array}{c}\text { Congo } \\
\text { Red }\end{array}$ & $\begin{array}{c}\text { Disperse } \\
\text { Red1 }\end{array}$ \\
\hline $3.35-4.75$ & 1.2 & 1.0 & 1.3 & 0.5 \\
$2.36-3.35$ & 3.1 & 4.5 & 8.9 & 4.5 \\
$1.18-2.36$ & 68.6 & 65.6 & 78.0 & 84.4 \\
$0.85-1.18$ & 16.4 & 16.2 & 7.1 & 6.8 \\
$0.60-0.85$ & 10.7 & 12.6 & 4.7 & 3.8 \\
\hline Total (\%) & 100 & 100 & 100 & 100 \\
\hline
\end{tabular}

\section{Surface area}

The porous structure is very important for dye molecules to be adsorbed on the biomass present inside the beads. The surface areas of the four kinds of beads in the size range of 1.18 to $2.36 \mathrm{~mm}$ are given in Table 4 . The beads containing autoclaved biomass had the highest value of $3.16 \mathrm{~m}^{2} / \mathrm{g}$. The other three kinds of beads had similar values from 2.40 to $2.86 \mathrm{~m}^{2} / \mathrm{g}$. Kapoor and Viraraghavan (1998) reported that the beads containing $\mathrm{NaOH}$ pretreated A. niger biomass and polysulphone had a surface area of 3.40 $\mathrm{m}^{2} / \mathrm{g}$, while the beads made from sphagnum peat biomass and polysulphone possessed a surface area in the range of 3.27 to 3.90 $\mathrm{m}^{2} / \mathrm{g}$, corresponding to the size range of 1.44 to $2.03 \mathrm{~mm}$ (Spinti et al., 1995). Therefore, the data on surface area are comparable with other studies.

\section{Dye removal by polysulphone beads}

The studies showed that polysulphone beads with a diameter less than $0.6 \mathrm{~mm}$ had some dye removal effects, depending on the dye structures. The adsorption capacities of polysulphone beads for the 
four dyes are given in Table 4. The polysulphone beads had the highest adsorption capacity for Basic Blue 9 $(1.70 \mathrm{mg} / \mathrm{g})$, while they had no removal effect on Congo Red.

\section{Column studies}

\section{Adsorption}

Figures 2 to 5 show the observed breakthrough points and the effluent $\mathrm{pH}$ for the adsorption of Acid Blue 29, Basic Blue 9, Congo Red and Disperse Red 1, vs. throughput volume, respectively. In the studies, the allowable breakthrough concentration was considered to be $0.15 \mathrm{C}_{0}$.

For Acid Blue 29, the value of $\mathrm{C} / \mathrm{C}_{0}$ increased gradually. When $\mathrm{C} / \mathrm{C}_{0}$ reached 0.15 , the throughput volume of the dye solution was approximately $1400 \mathrm{~m} \ell$ (50 bed volumes); when $\mathrm{C} / \mathrm{C}_{0}$ reached 0.5 , the throughput volume increased to approximately $5000 \mathrm{~m} \ell$ (170 bed volume); when the beads in the column were exhausted $\left(\mathrm{C} / \mathrm{C}_{0}=0.8\right)$, the throughput volume was approximately $12600 \mathrm{~m} \ell$ (420 bed volumes). The results indicated that the beads had a high adsorption capacity, but the adsorption capacity increased gradually. It took a long time for the beads to be saturated by the dye molecules of Acid Blue 29.

For Basic Blue 9, the value of $\mathrm{C} / \mathrm{C}_{0}$ increased faster than that of Acid Blue 29. When $\mathrm{C} / \mathrm{C}_{0}$ reached 0.15 , the throughput volume was approximately $240 \mathrm{~m} \ell$ (8 bed volumes); when $\mathrm{C} / \mathrm{C}_{0}$ increased to 0.5 , the throughput volume was approximately $660 \mathrm{~m} \ell$ (20 bed volumes); when the column was exhausted $\left(\mathrm{C} / \mathrm{C}_{0}=0.8\right)$, the throughput volume was approximately $1360 \mathrm{~m} \ell$ (40 bed volumes).

For Congo Red, the values of $\mathrm{C} / \mathrm{C}_{0}$ increased drastically under the two flow rates ( 3 and $6 \mathrm{~m} \ell / \mathrm{min}$ ). The column reached breakthrough very quickly. When $\mathrm{C} / \mathrm{C}_{0}$ reached 0.15 , the throughput volume was only about $5 \mathrm{~m} \ell$ ( 0.2 bed volume); when $\mathrm{C} / \mathrm{C}_{0}$ reached 0.5 , the throughput volume was approximately 30 to $40 \mathrm{~m} \ell$ ( 1 bed volume) for the two flow rates; when the beads in the column were exhausted $\left(\mathrm{C} / \mathrm{C}_{0}=0.8\right)$, the throughput volumes were approximately $380 \mathrm{~m} \ell$ (10 bed volumes) and $730 \mathrm{m \ell}$ ( 20 bed volumes) for the two flow rates of 6 and $3 \mathrm{~m} \ell / \mathrm{min}$, respectively. The lower flow rate increased the throughput volume at exhaustion.

For Disperse Red 1, the situation was similar to that of Congo Red. The column reached the breakthrough almost at the beginning. When $\mathrm{C} / \mathrm{C}_{0}$ reached 0.5 , the throughput volume was about $5 \mathrm{~m} \ell$ ( 0.2 bed volume) for the two flow rates; when the column was exhausted $\left(\mathrm{C} / \mathrm{C}_{0}=0.8\right)$, the throughput volumes were approximately $60 \mathrm{~m} \ell$ (2 bed volumes) and $45 \mathrm{~m} \ell$ (1.5 bed volumes) for the two flow rates of 6 and $3 \mathrm{~m} \ell / \mathrm{min}$, respectively, which were very low values.

For Acid Blue 29, the $\mathrm{pH}$ of effluent at the beginning was about 6.0, which was higher than the initial $\mathrm{pH}$ (4.0) of the dye solution. It then decreased gradually to a value of 4.2 and remained constant until the column was exhausted. This $\mathrm{pH}$ value was close to the initial $\mathrm{pH}$ of the dye solution. For Basic Blue 9, the pH of effluent at the beginning was about 7.0 which was higher than the initial $\mathrm{pH}$ (6.0) of the dye solution. It then decreased gradually

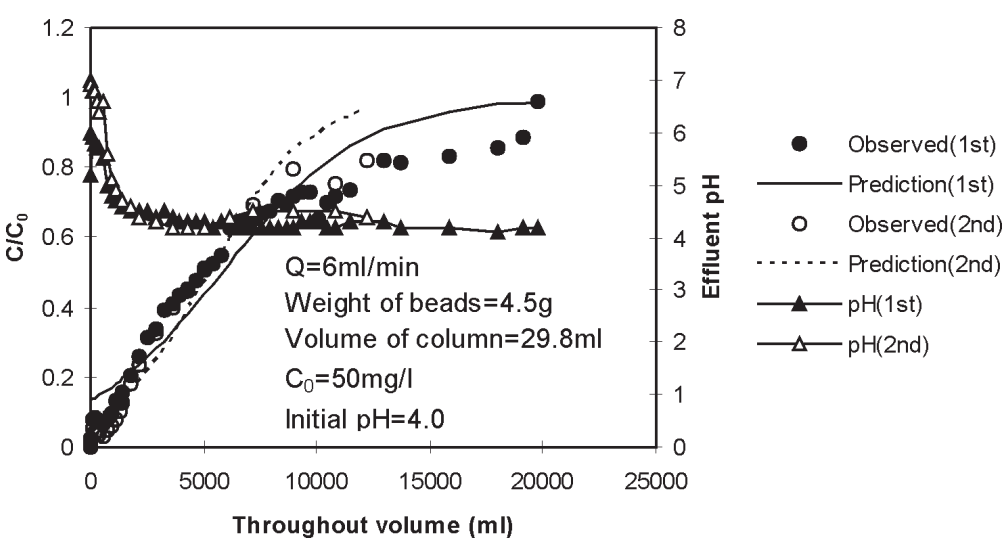

Figure 2

The observed breakthrough points and prediction curves by the Thomas model as well as effluent $\mathrm{pH}$ for Acid Blue 29

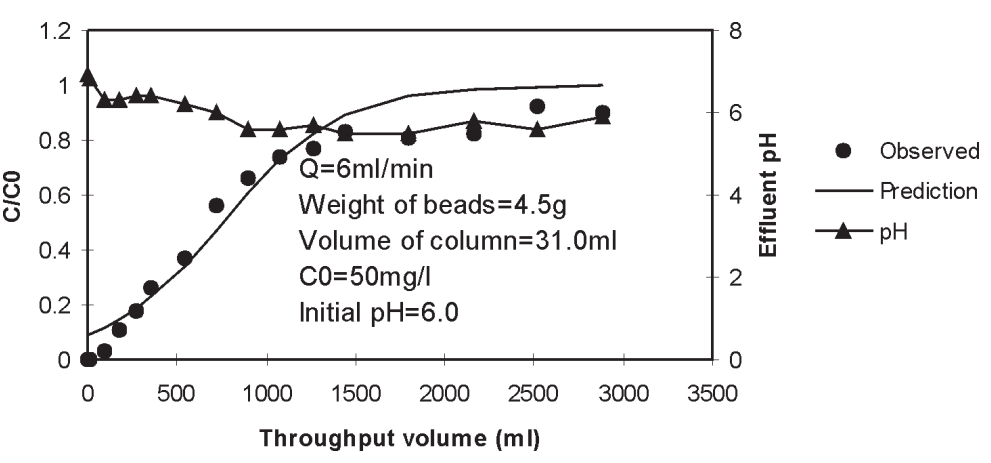

Figure 3

The observed breakthrough points and prediction curves by the Thomas model as well as effluent $\mathrm{pH}$ for Basic Blue 9

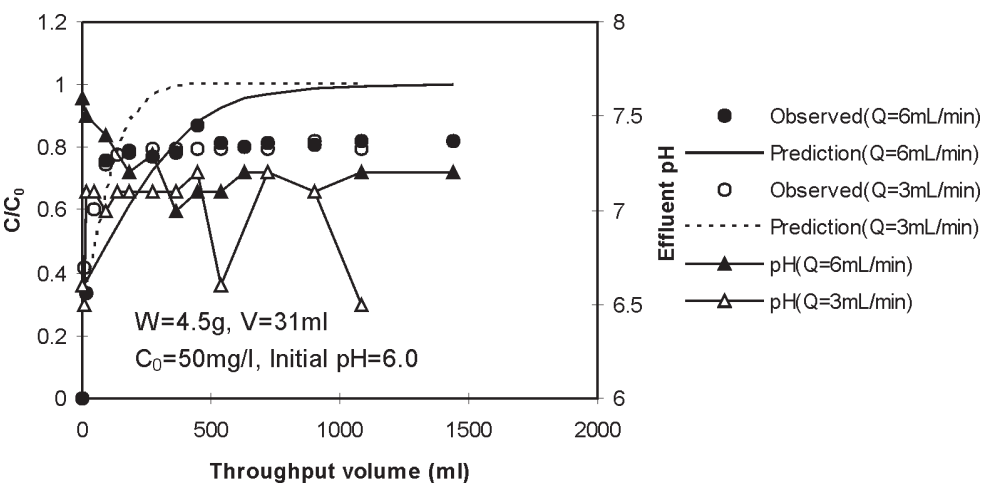

Figure 4

The observed breakthrough points and prediction curves as well as effluent pH for Congo Red

to a value of approximately 5.6 and maintained this value until the column was exhausted. For Congo Red, the $\mathrm{pH}$ of effluent at the beginning was 7.6 at the higher flow rate. It then decreased gradually to a value of approximately 7.2 and was constant until the column was exhausted. At the lower flow rate, the $\mathrm{pH}$ of effluent at the beginning was 6.6 and then increased to a value of 7.1. There were some fluctuations of $\mathrm{pH}$ close to the exhaustion of the column. For Disperse Red 1, the values of effluent $\mathrm{pH}$ at the beginning were almost the same (approximately 7.0) at the two flow rates. All then decreased gradually to a value of approximately 4.2 , and this value remained constant 


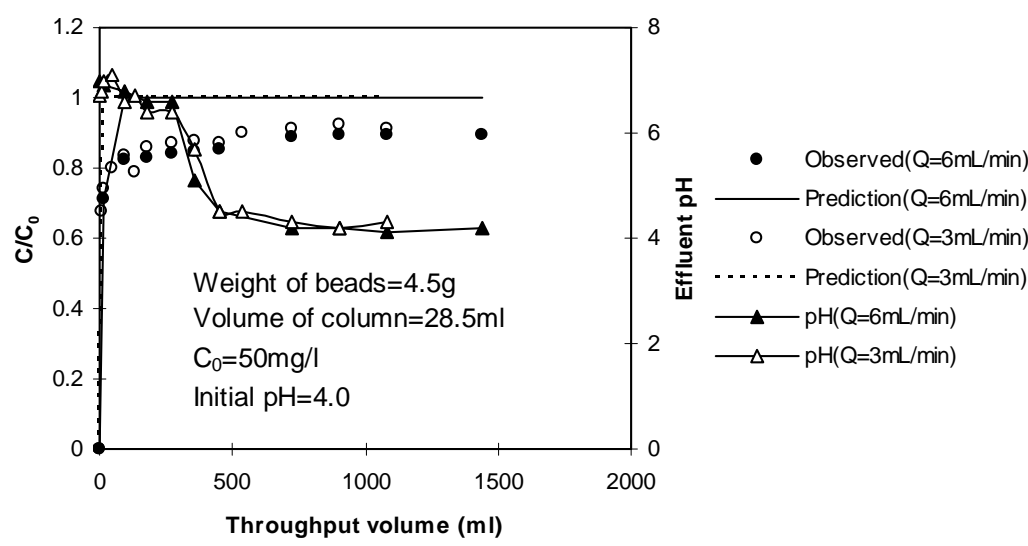

Figure 5

Observed breakthrough points and prediction curves by the Thomas model as well as effluent $\mathrm{pH}$ for Disperse Red 1

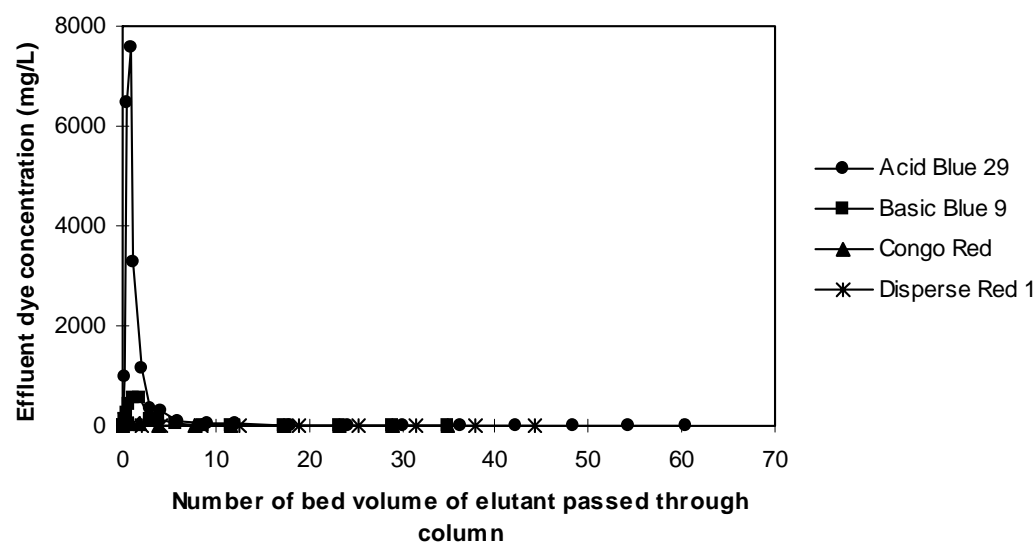

Figure 6

Elution curve for dye desorbed from beads in column

until the exhaustion of the column, which was close to the initial $\mathrm{pH}$ of the dye solution.

The breakthrough data from column studies for Acid blue 29, Basic Blue 9, Congo Red and Disperse Red1 adsorption were fitted to the Thomas model shown in Eq. (3) and the constants of a and b were obtained after regression analysis. These constants and related statistical parameters are given in Table 6. The Thomas model constants, $\mathrm{k}_{\text {and }} \mathrm{q}_{0}$ were calculated according to Eqs. (6) and (7) and are given in Table 6. Figures 2 to 5 also show the prediction curves by the Thomas model for these four dyes' adsorption, respectively. Table 6 shows that the beads had the highest adsorption capacity for Acid Blue 29 (64.7 mg/g), while the beads had a much lower value for Basic Blue $9(8.3 \mathrm{mg} / \mathrm{g})$. The beads had a very low adsorption capacity for Congo Red and Disperse Red 1 , and the lower flow rate corresponded to the lower adsorption capacity. The t-test showed that all the constants for Acid Blue 29 and Basic Blue 9 estimated by the Thomas model were statistically significant at the 95\% confidence level, while the constants for Congo Red were not. The t-test was not available for the constants of Disperse Red 1 even though the correlation coefficient $\mathrm{R}$ was not low. Because the two columns for Congo Red and Disperse Red 1 reached the breakthrough point in very short time, it resulted in limited data being obtained before the breakthrough point and caused unsatisfactory t-test results. When the flow rate for these two dyes was reduced to half, the situation was still the same as before.

The beads consisted of two-third fungal biomass and one-third polysulphone by weight. In this study, the adsorption capacity contributed from polysulphone in the biomass-polysulphone beads was assumed zero. Therefore, the adsorption capacity contributed by the biomass in the biomasspolysulphone beads was 1.5 times of the adsorption capacity of the biomass-polysulphone beads and given in Table 6. Table 6 also gives the values of adsorption capacities $\left(\mathrm{Q}^{0}\right)$ for the four dyes obtained in batch studies, using the powdered $A$. niger fungal biomass. For Acid Blue 29, the biosorption capacity of the biomass in the beads increased by approximately $8 \%$,compared to that of the powdered biomass while it decreased to approximately $25 \%$ for Basic Blue 9. In the case of Congo Red and Disperse Red 1, the biomass in the beads adsorbed much less, compared to that of the powdered biomass. These results seem to indicate that the immobilisation of biomass into the polysulphone matrix might influence dye adsorption on the biomass in the beads negatively. This may be due to the organic solvent, DMF, which might cause chemical modifications to fungal biomass. This requires further detailed study.

\section{Elution}

When the beads in the column became exhausted with dyes, the dyes were eluted by their corresponding elutants (Table 2). Figure 6 shows the concentration of the four dyes in the elutants vs. the volume of elutants (in bed volumes), respectively. The majority of the adsorbed dyes in the beads were eluted in approximately 10 bed volumes. Due to the high adsorption capacity of the beads for Acid Blue 29, the peak dye concentration in the elutant was very high, approximately $7500 \mathrm{mg} / \ell$, which indicated that this dye could be recovered. The total amounts of dyes adsorbed on and desorbed from the beads were calculated by integrating the breakthrough data and elution data, respectively and the desorption rates for the four dyes were thus obtained. They were $69.6 \%$ for Acid Blue 29, 90.7\% for Basic blue 9, 43.9\% for Congo Red and 59.7\% for Disperse Red 1, respectively, which were consistent with the results in batch elution studies (data not shown). The performance of elution for Acid Blue 29 and Basic Blue 9 from the beads was acceptable while for Congo Red and Disperse Red 1 it was poor. In the elution studies, it was observed that the biomass-ploysulfone beads were stable after elution with $\mathrm{HCl}$ and $\mathrm{NaOH}$.

\section{Reuse of the regenerated beads for Acid Blue 29}

After regeneration by deionised water, the beads were reused in the column for Acid Blue 29 removal. Figure 3 shows the observed breakthrough points and the effluent $\mathrm{pH}$ vs. throughput volume in the second column adsorption cycle for Acid Blue 29. The observed breakthrough points in the second adsorption cycle were close to those in the first. The value of $\mathrm{C} / \mathrm{C}_{0}$ also increased gradually. When $\mathrm{C} / \mathrm{C}_{0}$ reached 0.15 , the throughput volume was approximately $1600 \mathrm{~m} \ell$ ( 55 bed volumes), which was higher than that in the first cycle (1400 $\mathrm{m} \ell, 50$ bed volumes). When $\mathrm{C} / \mathrm{C}_{0}$ reached 0.5 , the throughput volume increased to approximately 
TABLE 6

The Thomas model constants obtained by non-linear regression analysis for the column studies

\begin{tabular}{|c|c|c|c|c|c|c|c|c|}
\hline Dye & $\begin{array}{l}\text { Statistical } \\
\text { parameter }\end{array}$ & $a(1 / m \ell)$ & b & $\mathbf{R}$ & $\begin{array}{c}\mathbf{k} \\
\text { (melmin. } \\
\text { mg beads) }\end{array}$ & $\begin{array}{c}q_{0} \\
\text { (mg/g } \\
\text { beads) }\end{array}$ & $\begin{array}{c}\mathrm{q}_{0} \mathrm{mg} / \mathrm{g} \\
\text { biomass } \\
\text { in beads }\end{array}$ & $\begin{array}{c}\mathrm{Q}^{0} \mathrm{mg} / \mathrm{g} \\
\text { powdered } \\
\text { biomass }\end{array}$ \\
\hline $\begin{array}{l}\text { Acid Blue } 29 \\
\left(1^{\text {st }} \text { cycle }\right) \\
(\mathrm{Q}=6 \mathrm{~m} \ell / \mathrm{min})\end{array}$ & $\begin{array}{l}\mathrm{N}=45 \\
\text { Std. Err. } \\
\mathrm{t}(43) \\
\text { p-level }\end{array}$ & $\begin{array}{c}0.00032 \\
0.00002 \\
12.87 \\
0.000\end{array}$ & $\begin{array}{c}1.86 \\
0.14 \\
13.53 \\
0.000\end{array}$ & 0.96 & 0.04 & 64.7 & 97.1 & 89.7 \\
\hline $\begin{array}{l}\text { Acid Blue } 29 \\
\left(2^{\text {nd }} c y c l e\right) \\
(\mathrm{Q}=6 \mathrm{~m} \ell / \mathrm{min})\end{array}$ & $\begin{array}{l}\mathrm{N}=23 \\
\text { Std. Err. } \\
\mathrm{t}(21) \\
\text { p-level }\end{array}$ & $\begin{array}{c}0.00047 \\
0.00005 \\
9.48 \\
0.000\end{array}$ & $\begin{array}{c}2.48 \\
0.20 \\
12.33 \\
0.000\end{array}$ & 0.97 & 0.06 & 59.1 & 88.7 & NA \\
\hline $\begin{array}{l}\text { Basic Blue } 9 \\
(\mathrm{Q}=6 \mathrm{~m} \ell / \mathrm{min})\end{array}$ & $\begin{array}{l}\mathrm{N}=16 \\
\text { Std. Err. } \\
\mathrm{t}(14) \\
\text { p-level }\end{array}$ & $\begin{array}{c}0.00305 \\
0.00050 \\
6.07 \\
0.000\end{array}$ & $\begin{array}{c}2.31 \\
0.34 \\
6.78 \\
0.000\end{array}$ & 0.97 & 0.4 & 8.3 & 12.5 & 15.5 \\
\hline $\begin{array}{l}\text { Congo Red } \\
(\mathrm{Q}=6 \mathrm{~m} \ell / \mathrm{min})\end{array}$ & $\begin{array}{l}\mathrm{N}=13 \\
\text { Std. Err. } \\
\mathrm{t}(11) \\
\text { p-level }\end{array}$ & $\begin{array}{c}0.00577 \\
0.00822 \\
0.70 \\
0.498\end{array}$ & $\begin{array}{c}0.58 \\
0.89 \\
0.65 \\
0.530\end{array}$ & 0.69 & 0.7 & 1.1 & 1.7 & 8.2 \\
\hline $\begin{array}{l}\text { Congo Red } \\
(\mathrm{Q}=3 \mathrm{~m} \ell / \mathrm{min})\end{array}$ & $\begin{array}{l}\mathrm{N}=45 \\
\text { Std. Err. } \\
\mathrm{t}(43) \\
\text { p-level }\end{array}$ & $\begin{array}{c}0.01584 \\
0.01314 \\
1.20614 \\
0.251\end{array}$ & $\begin{array}{l}0.86 \\
0.60 \\
1.44 \\
0.18\end{array}$ & 0.70 & 1.0 & 0.6 & 0.9 & 8.2 \\
\hline $\begin{array}{l}\text { Disperse Red } 1 \\
(\mathrm{Q}=6 \mathrm{~m} \ell / \mathrm{min})\end{array}$ & $\begin{array}{l}\mathrm{N}=11 \\
\text { Std. Err. } \\
\mathrm{t}(9) \\
\text { p-level }\end{array}$ & $\begin{array}{c}1.33689 \\
\text { NA } \\
\text { NA } \\
\text { NA }\end{array}$ & $\begin{array}{l}15.13 \\
\text { NA } \\
\text { NA } \\
\text { NA }\end{array}$ & 0.86 & 160.4 & 0.1 & 0.2 & 6.3 \\
\hline $\begin{array}{l}\text { Disperse Red } 1 \\
(\mathrm{Q}=3 \mathrm{~m} \ell / \mathrm{min})\end{array}$ & $\begin{array}{l}\mathrm{N}=45 \\
\text { Std. Err. } \\
\mathrm{t}(43) \\
\text { p-level }\end{array}$ & $\begin{array}{c}1.05637 \\
\text { NA } \\
\text { NA } \\
\text { NA }\end{array}$ & $\begin{array}{l}5.59 \\
\text { NA } \\
\text { NA } \\
\text { NA }\end{array}$ & 0.78 & 63.4 & 0.1 & 0.2 & 6.3 \\
\hline
\end{tabular}

$5000 \mathrm{~m} \ell$ (170 bed volumes) almost the same as that in the first cycle. When the column was exhausted $\left(C / C_{0}=0.8\right)$, the throughput volume was approximately $12000 \mathrm{~m} \ell$ ( 400 bed volumes) lower than that in the first cycle (12 $600 \mathrm{~m} \ell, 420$ bed volumes). The change of the effluent $\mathrm{pH}$ in the second adsorption cycle was nearly the same as that in the first cycle.

The breakthrough data in the second adsorption cycle for Acid Blue 29 was also fitted to the Thomas model and the results are given in Table 6. Figure 3 also shows the prediction curve by the Thomas model for the second adsorption cycle. The t-test showed that the Thomas constants were also statistically significant at the 95\% confidence level, like those in the first cycle. In the second cycle, the adsorption capacity of the biomass-polysulphone beads was over $91 \%$ of that in the first cycle, which showed a good potential to develop a system using immobilised A. niger biomass for the removal of certain dyes from aqueous solutions.

\section{Conclusions}

A. niger fungal biomass can be immobilised into polysulphone solid matrix to form spherical biomass-polysulphone beads. The beads had a porous structure with a specific surface area in the range of 2.40 to $3.16 \mathrm{~m}^{2} / \mathrm{g}$ (diameter of the beads: 1.18 to $2.36 \mathrm{~mm}$ ). The effective size of beads was in a range of 0.7 to $1.1 \mathrm{~mm}$ and 60 to $80 \%$ of the beads ranged between 1.18 and $2.36 \mathrm{~mm}$ in size. The biomass-polysulphone beads exhibited excellent handling characteristics in columns and were stable in acid and base solutions.

Column studies for the removal of four dyes from aqueous 
solutions indicated different performances, dependent upon the dye structure. For Acid Blue 29, the beads in the column possessed the highest adsorption capacity. At column exhaustion, the throughput volume was as high as 420 bed volumes. For Basic Blue 9, the adsorption capacity of the bead was much lower than that for Acid Blue 29, its throughput volume at exhaustion was 40 bed volumes. In contrast, the columns reached breakthrough point and exhaustion in a shorter time for Congo Red and Disperse Red 1.

The breakthrough data from the column studies can be described by the Thomas model. The t-test showed that all the constants for adsorption of Acid Blue 29 and Basic Blue 9 were statistically significant at $95 \%$ confidence level, but not for Congo Red adsorption. The t-test was not available for the constants of Disperse Red 1 adsorption.

The elution studies showed that Acid Blue 29 and Basic Blue 9 could be easily eluted from the beads with desorption rates of approximately $70 \%$ and $90 \%$, respectively, while Congo Red and Disperse Red 1 were difficult to be eluted with desorption rates of approximately $40 \%$ and $60 \%$, respectively.

The regeneration and reuse studies indicated that the beads for Acid Blue 29 could be regenerated by deionised water and the reused beads could retain over $90 \%$ of the original adsorption capacity of the beads. These results suggest that treatment systems using the beads of immobilised $A$. niger biomass in polysulphone could be developed for the removal of some dyes from aqueous solutions.

\section{Further research}

The ratio of the amount of biomass to polysulphone in the slurry used for the beads production would affect the pore structure and dye removal capacity of the beads. Therefore, the optimal ratio should be studied to produce the beads with a proper pore structure and high dye removal capacity.

In the slurry preparation, the organic solvent, DMF, dissolves polysulphone. This might cause some chemical modifications to the fungal biomass, which could cause some influence on the adsorption capacity of the biomass in the beads. These effects should be studied further.

\section{Acknowledgements}

The study was supported by a research grant from the Natural Sciences and Engineering Research Council of Canada to the second author. The first author thanks the Faculty of Graduate Studies and Research and the Faculty of Engineering for partial support during the study.

\section{References}

BANAT IM, NIGAM P, SINGH, D and MARCHANT R (1996) Microbial decolorization of textile-dye-containing effluents: A review. Bioresour. Technol. 58 217-227.

BANKS CJ and PARKINSON ME (1992) The mechanism and application of fungal biosorption to colour removal from raw waters. J. Chem. Technol. and Biotechnol. 54 192-196

BENITO GG, MIRANDAMP and DE LOS SANTOS DR (1997) Decolorization of wastewater from an alcoholic fermentation process with Trametes versicolor. Bioresour. Technol. 61 33-37.

BRIERLEY CL (1990) Metal immobilization using bacteria. In: Ehrlich HL and Brierley CL (eds.) Microbial Mineral Recover. McGraw-Hill Publishing Company, USA. 303-323.
DAS BM (1997) Sieve analysis. In: Soil Mechanics Laboratory Manual (5th edn.) Engineering Press, Austin, Texas, USA. 15-22.

FERGUSON CR, PETERSON MR and JEFFERS TH (1989) Removal of metal contaminants from waste waters using biomass immobilized in polysulfone beads. In: Scheiner BJ, Doyle FM and Kawatra SK (eds.) Biotechnology in Minerals and Metal Processing. Society of Mining Engineers, Inc., Littleton, Colorado, USA.

FU Y and VIRARAGHAVAN T (1999) Removal of Acid Blue 29 from an aqueous solution by fungus Aspergillus niger. In: Nikolaidis N, Erkey C and Smets B (eds.) Proc. 31 ${ }^{\text {st }}$ Mid-Atlantic Ind. and Hazardous Waste Conf. Lancaster, Pennsylvania: Technomic Publishing Co., Inc. USA. 510-519.

FU Y and VIRARAGHAVAN T (2000) Removal of a dye from an aqueous solution by fungus Aspergillus niger. Water Qual. Res. J. Canada 35 95-111.

GADD GM (1990) Biosorption. Chem. and Ind. 2 (13) 421-426.

GALLAGHER KA, HEALY MG and ALLEN SJ (1997) Biosorption of synthetic dye and metal ions from aqueous effluents using fungal biomass. In: Wise DL (ed.) Global Environmental Biotechnology. Elsevier Science B V, UK. 27-50.

KAPOOR A and VIRARAGHAVAN T (1995) Fungal biosorption - An alternative treatment option for heavy metal bearing wastewater: A review. Bioresour. Technol. 53 195-206.

KAPOOR A and VIRARAGHAVAN T (1998) Removal of heavy metals from aqueous solutions using immobilized fungal biomass in continuous mode. Water Res. 32 1968-1977.

KNAPP JS, NEWBY PS and REECE LP (1995) Decolorization of dyes by wood-rotting Basidiomycete fungi. Enzyme and Microb. Technol. 17 664-668.

MIRANDA MP, BENITO GG, CRISTOBAL NS and NIETO CH (1996) Color elimination from molasses wastewater by Aspergillus niger. Bioresour. Technol. 57 229-235.

MISHRA G and TRIPATHY M (1993) A critical review of the treatment for decolorization of textile effluent. Colourage 40 35-38.

MOU DG, LIM KK and SHEN HP (1991) Microbial agents for decolorization of dye wastewater. Biotechnol. Adv. 9 613-622.

POLMAN JK and BRECKENRIDGE CR (1996) Biomass-mediated binding and recovery of textile dyes from waste effluents. Text. Chem. Color. 28 (4) 31-35.

REIFE A (1990) Waste treatment of soluble azo acid, direct and reactive dyes using a sodium hydrosulfite pretreatment followed by carbon adsorption. In: AATCC Book of Papers. 1990 Int. Conf. and Exhib., October 1-3, Philadelphia, USA.

REIFE A and FREEMAN HS (1996) Carbon adsorption of dyes and selected intermediates. In: Environmental Chemistry of Dyes and Pigments. John Wiley \& Sons, Inc., USA. 7 pp.

REYNOLDS TD and RICHARDS PA (1996) Unit Operations and Processes in Environmental Engineering ( $2^{\text {nd }}$ edn.). PWS, Boston, USA.

SPINTI M, ZHUANG H and TRUJILLO EM (1995) Evaluation of immobilized biomass beads for removing heavy metals from wastewaters. Water Environ. Res. 67 943-952.

THOMAS HG (1948) Chromatography: A problem in kinetics. Ann. N. Y. Acad. Sci. 49 161-182.

TOBIN JM, L'HOMME B and ROUX JC (1993) Immobilisation protocols and effects on cadmium uptake by Rhizopus arrhizus biosorbents. Biotechnol. Techniques 7 739-744.

TSEZOS M (1990) Engineering aspects of metal binding by biomass. In: Ehrlich HL and Brierley CL (eds.) Microbial Mineral Recovery. McGraw-Hill Publishing Company, USA. 325-339.

TSEZOS M and DEUTSCHMANN AA (1990) An investigation of engineering parameters for the use of immobilized biomass particles in biosorption. J. Chem. Tech. Biotechnol. 48 29-39.

VASDEV K, KUHAD RC and SAXENA RK (1995) Decolorization of triphenylmethane dyes by the bird's nest fungus Cyathus bulleri. Curr. Microbiol. 30 269-272.

ZHOU JL and BANKS CJ (1993) Mechanism of humic acid colour removal from natural waters by fungal biomass biosorption. Chemosphere 27 (4) 607-620. 